\title{
INCREASING ENVIRONMENTAL AWARENESS TO OVERCOME LACK OF NATURAL RESOURCES THROUGH CHARACTER BUILDING BASED ON MICROECONOMIC THEORY
}

\author{
Yopi Nisa Febianti; Dian Permana Putri \\ Economic Education Department, Universitas Swadaya Gunung Jati, Indonesia \\ E-mail: taniabekker@yahoo.com_
}

\begin{abstract}
This research aims to assess students awareness attitude on natural resources in the region of Unswagati Cirebon Indonesia. Qualitative research method is used in this study involving 87 students as sample at the second grade of Economic Education FKIP Unswagati in the year of 2016/2017. Data were gathered using interviews, observation, and documents. These were analyzed employing qualitative technique through developing the domains, taxonomies, compositions, and cultural themes. Results indicate that the students have positive attitudes towards their environment while using natural resources, having sufficient knowledge and skills in maintaining, managing, preserving, and restoring the environment to overcome the lack of natural resources.
\end{abstract}

Keywords -Environmental awareness, natural resources, character building, microeconomic theory

\section{INTRODUCTION}

Natural resources are an essential resource for human survival in this hemisphere. The loss of natural resources impacts human life. People for example cannot live without air and water. They also depend on other resources such as forests, fishery, soil, wind, and sunlight. These not only fulfill human needs, but also provide great contributions to the prosperity of a nation.

In general, natural resources can be classified into two groups. There are non-renewable natural resources and renewable natural resources. Both types of resources are limited. If they are depleted, there will be no longer available in the future.

Mineral resources, metallic, petroleum and natural resources are limited. Meanwhile, forests, fish, soil, wind, and sunlight are unlimited. Both must be managed efficiently as possible. However, although the renewable resources are available, when these are not well managed, these resources will be depleted too. Proper management of natural resources improves the prosperity of human life.

Natural resources have to be managed properly. The activities of exploration and the use of natural resources must not destroy surrounding environments. This way is necessary in order to protect the quality of natural resources. Thus, they can provide more benefits for people. Through saving the resources, the availability of natural resources can be sustained.

There are many ways that can human do to maintain or preserve the environment, such as reforestation, terracing/swales, selective logging, recycling, irrigation, sewage processing, the production of eco-friendly goods, reclamation, the establishment of conservation, etc. This is done to keep environment always in a good condition, because the environment is a place where people can maintain a prosperous survival. Moreover, the environment is also a place of the availability of various natural resources, both renewable and non-renewable natural resources.

Education becomes an important part for achieving environmental sustainability. Environmental Education is an effort to change the behaviour and attitude of various elements of society, with the aim of increasing knowledge, skills, and public awareness about the values and issues of environmental problem. It can ultimately mobilize the society to actively involved in conservation efforts, and for the safety of the environment now and in the future (PIL,2009). Environmental Education has communication purpose between the messenger 
and the recipient of the message, or someone who is targeted by the Environmental Education. The communication purpose here means the changing of knowledge, attitude, and behaviour. For example, someone who doesn't care to the damage of the surrounding environment becomes active in preserving the environment. Caring for the environment is also reflected in the environmental character building. The value of environmental care is to increase awareness, concern, and responsibility for the environment. Building an environmental awareness character is part of the Environmental Education.

One of the courses that take a part in improving students' environmental awareness is Microeconomic Theory course. In this course there is a topic about the theory of scarcity. In the theory of scarcity there is a sub-topic about the steps in overcoming the scarcity of natural resources.

\section{METHOD}

The research method used in this research is qualitative research method. According to Sugiyono (2014: 8), "Qualitative research methods are often called naturalistic research methods because the research is done on natural conditions (natural settings)". Qualitative research is a research conducted by thinking criticallyscientific based on the facts or social phenomena that obtained directly from the field, then analyzed, therefore there will created a new theory that is useful for science. The use of qualitative methods in this research is to illustrate the environmental awareness of students in Unswagati Cirebon in overcoming the scarcity of natural resources and also to describe the influence of environmental awareness level of students in Unswagati Cirebon to overcome the scarcity of natural resources through environmental character building.

In this research, the research place or social situation is the Campus of FKIP Unswagati Cirebon. Meanwhile, the time of this research is during the first semester 2016/2017; for 3-4 months, and 2 months in the second semester 2016/2017. Thus, the entire time of this research is approximately 7 months. Instrument of this research is the researcher itself with the total 2 persons and assisted by students which the total 4 persons. In this research there are additional instruments; observation sheets, interview sheets, and questionnaires.

In this research, the sample was chosen using sampling technique; nonprobability sampling. Nonprobability sampling is a sampling technique that does not provide equal opportunities for each element or member of the population to be selected as sample (Sugiyono, 2014: 218). The Nonprobability sampling that used is purposive sampling. Purposive sampling is a technique of data source sampling with certain considerations (Sugiyono, 2014: 218-219). The data sources in this research consist of primary data and secondary data. The primary dataare questionnaires distributed to Economics Education second grade students of FKIP Unswagati, with the total 87 people as participants, while the secondary data are data of observation, interview, and documentation (in the form of photographs).

Technique and data collection used in this research were as followed: (1) Observation, the technique of data collection through observation of social situations that occur for a research. In this research, the observation that used is participative observation, both active and passive participation to make descriptive observation (2) Interview, is technique of data collection in the form of research information report. The interview that used was structured and open interviews. (3) Questionnaires, is technique of data collection in the form of a list of written questions which are distributed to informants/ participants to be filled and reassembled. The questionnaire that used was a questionnaire containing positive and negative statements. (4) Documentation,is technique of data collection in the form of various literatures or photographs related to the concept of the research discussion.

The steps of qualitative data analysis in this research are: (1) Domain analysis. The result of this analysis is still in the form of basic level knowledge which aimed as exploration. (2) Taxonomic analysis. Researchers can explore important domains and sub domains through consultation with references to gain a deeper understanding. (3) Component analysis. The activity of this analysis begins with the stage of the results of data collection (observation, interview, questionnaire, and documentation) (4) Analysis of cultural themes. Researchers perform reconstruction in the form of descriptive, 
narratives, and arguments. In this analysis, researchers can draw conclusions in general according to research objectives.

\section{RESULT}

In this chapter, the research data are described in order to find out how is awareness of students in Unswagati Cirebon to overcome the scarcity of natural resources. It also investigated the character building program towards the efforts to overcome the scarcity of natural resources.Specifically, this research is conducted as an effort to increase environmental awareness in overcoming the scarcity of natural resources through the education of environmental awareness character.Because ofthatpurpose, it needs a research data in the form of response from the object of the research (participants). The participants in this research were the second grade students of Economics Education of FKIP Unswagati academic year 2016/2017 who took Microeconomic Theory course with the total 87 students.

In collecting data through observation, the researcher observed the student's environmental caring attitude at the beginning of learning activity, the coreof learning activity, and the end of learning activity.Observation has done four times during lecturesdiscussing about scarcity.Through the interview, the researcher spread the interview sheets to theparticipants to give their written answers about their environmental caring attitude in overcoming the scarcity of natural resources. The interview sheet contains of 5 questions. Through the questionnaire, the researcher gave a questionnaire about the students' environmental awareness in overcoming the scarcity of natural resources that must be filled to the participants. The questionnaire that the researcher gave contained 35 statements, consisting of positive statements and negative statements.Meanwhile, through the documentation, it can be clearly known how the students' environmental caring attitude are.

Based on the research that has been conducted through observation, the researcher thought that the students are still being ignorant to the cleanliness, maintenance, and also the preservation of the surrounding environment, especially the students' attitude toward the waste and the scarcity of natural resources. This can be seen in the classroom, when students attended the class, they did not care about the cleanliness of the class (there is trash) and cluttered class conditions (messy chairs and graffiti on the whiteboard), as well as wasteful use of lighting (Lights are still on during the day or the weather conditions are bright).Students will immediately clean up the classroom, tidy up the chairs, remove the graffiti, and turn off the lights when the lecturer, who was in charge of teaching in that class, asked them. Students will be aware of the environment if it has been orered to do so. They cannot take the initiative to concern about the environment.

Based on research that has been conducted through interview from 40 students, the researchers obtained the result that all respondents have realized thatit is very important to utilize natural resources economically and wisely. Most of the students $(96 \%)$ stated that the use of natural resources should be wise and efficient, so that the limited amount of natural resources can be experienced by the next generations and there is no scarcity.The various efforts that have been done by respondents to prevent scarcity of natural resources are:saving water usage; turn off the water tap; Save electricity usage; and reduce the use of plastics, paper and tissues, as well as fuel. Planting trees around the dwellings and trying notto cut the tree down carelessly. According to all respondents (100\%), the scarcity of natural resources that cannot be overcome by humans will make human suffer and human beings will probably become extinct,because human life depends on the availability of natural resources. All of aspects of human life, such as breathing, eating, drinking, as well as clothingand all basic necessitiescan be fulfilled by the availability of natural resources.Although some needs, such as clothing and shelter can be replaced with synthetic materials derived from chemical materials,it is different from food needs that cannot be replaced with artificial ingredients. The Microeconomics theory course which discussed about scarcity theory and the education of environmental awareness character caused almost all respondents $(90 \%)$ realizedto involve in beneficial activities to overcome the scarcity of natural resources. Although still on a small scale, but the desire and motivation to try to overcome the scarcity of natural resources 
should be appreciated.Nevertheless, there were 4 respondents from a total40 respondents who stated that they have not been realized and aware yet to participate in activities to overcome the scarcity of natural resources. The reasons for these respondents were because they have limited time and energy.All respondents expressed their interest to invite some friends around them to involve in beneficial activities to overcome the scarcity of natural resources, and increasing an environmental awareness attitude in the future. Environmental attitudes can be obtained through the education of environmental awareness characters.By growing a caring attitude, it will indirectly change a person's mindset in action, so activities to prevent future scarcity of natural resources will be easier to do.

Based on the research that has been conducted through questionnaires, the researchers obtained the data in the form of results of questionnaires that given to secondgrade students of Economic Education of FKIP Unswagati. From the results of questionnaires that researchers have obtained, then calculating and percentage of each item statement that has been answered by the students. After the data has been presented, the researcher performs the recapitulation and description of each item of statement, and then continues on the analysis and the final conclusion of the questionnaire results. The conversion of data into a percentage is done by counting the total of students' answers, divided by the number of students who completed the questionnaire, then multiplied by 100 . The result of the participation of the second grade students of Economic Education of FKIP Unswagati can be described as follows.

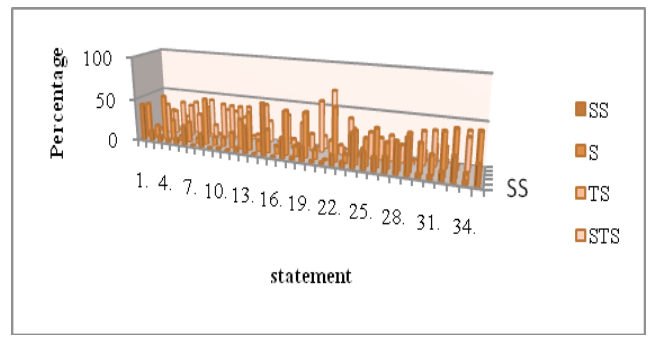

\section{Figure 1 Data Result of Questionnaire}

From the chart above it can be seen that most second grade students of Economics Education of FKIP Unswagati expressed their concern to the environment in overcoming the scarcity of natural resources through environmental care attitude.
They prove it by stating that they always maintain personal hygiene, rooms, homes, classrooms, campus, and the surrounding environment with a great responsibility, without being reminded and ordered by others (parents, teachers, and friends), that is by maintaining the cleanliness of public facilities, always cast the trash to the trash can, sparing useing plastic bags that cannot be recycled, and remind each other in maintaining cleanliness and environmental sustainability. They are also always trying to make savings of natural resources (electric energy and fuel oil), healthy living, as well as unpretentious life.

Based on the research results obtained through documentation (photographs), the researchers saw that there are some students who have a sense of care for cleanliness, maintenance, and environmental conservation in overcoming the scarcity of natural resources, but there are also some students who are still ignorant on cleanliness, maintenance, and environmental conservation in overcoming the scarcity of natural resources.It can be concluded that developing a caring attitude towards the environment in overcoming scarcity of natural resources to a person will be easy if the person consciously initiative and self-motivated to do it. If they have to be constantly reminded or ordered or to be warned, they will continuously being ignorant.

\section{DISCUSSION}

\section{Students' Environment Concern Unswagati Cirebon in Overcoming Scarcity of Natural Resources}

The scarcity of natural resources is a condition that all of us afraid of, but it can be overcome by doing a preventive effort for the scarcity of natural resources, or we can make an effort to prevent the scarcity of natural resources from happening. Many efforts that can be done to prevent or overcome the scarcity of natural resources, one of them is to save the usage of natural resources in our surroundings.In accordance with of Ahman and Rohmana (2009:3) who said that, "Scarcity is the core of economic problems, because the scarcity of economic resources demand people to make sacrifices, whether in the form of energy, thought, money, opportunity, and time to obtain it.From that opinion, we knew that to prevent and overcome the scarcity of natural resources 
required a sacrifice, both material and nonmaterial.The material sacrifice that we can do is to reduce our comfort condition by reducing the energy resources (nature), such as use electricity efficiently, water, and fuel, also recycling goods that are still fit to use. Another sacrifice that can be done (non-material) is to realize the importance of sustainability and cleanliness of our environment in creating harmony and balance of the environment by continuing to develop the attitude of environmental care. If we know the importance of healthy and clean living, thus we will always try to create the sustainable environment around us. The preservation of the environment is an effort to overcome the scarcity of natural resources, because we are economizing in using the natural resources.

Natural environment and natural resources are two interrelated factors, because the natural resources that people need come from the natural environment, both natural resources that renewable and non-renewable. We must be thrifty in using non-renewable resources (fuel), by reducing the use of vehicles for everyday activities. In addition, we also must be thrifty in using the natural resources that renewable (water), because the natural resources will be depleted if we are wasteful in using them. thrifty in using natural resources means we maintain our health and personal hygiene.

From the results of observation, interview, questionnaire, and documentation, it is known that the second grade students of Economics Education of FKIP Unswagati have an environmental attitude and thrifty in using natural resources. Although caring and thrifty attitude is not done continuously. Sometimes they care and save, while the others are ignorant. However, they are always aware that environmental care attitudes means that they participated in environmental conservation efforts to overcome the scarcity of natural resources, respecting nature (maintaining environment cleanliness); Responsible (not littering); Solidarity (reminding each other's about personal hygiene and environment); Affection and care (preserving the environment); Not harmful (thrifty in using natural resources); Living unpretentious and harmony with nature (healthy life); Justice (sharing with others in the use of natural resources and environmental sustainability); Democracy (everyone has the right to maintain and preserve the environment, and thrifty to use natural resources); And moral integrity (environmental caring attitudes). Those statements is in accordance with the opinion of Sony Keraf (Setyono, 2011: 28) who said that, the principles of environmental ethics, are: (1) Respect for nature; (2) Principles of responsibility; (3) Cosmic Solidarity; (4) Love and caring for nature; (5) No harmful; (6) Unpretentious and in harmony with nature; (7) Justice; (8) Democracy; and (9) Moral integrity.

Students should try to apply the principles of environmental ethics, the easiest way is to live healthy and clean, maintain personal hygiene and the environment. The sustainable natural environment will have a positive impact on human life, which is the availability of great natural resources, of course, the renewable natural resources, such as water. Water is the natural environment that can generate electrical energy that plays an important role in the mobility of human life.

\section{The Influence of Character Education on the awareness of Environment for Students of Unswagati Cirebon in Overcoming Scarcity of Natural Resources}

Education is an effort to increase the individual awareness formally. Education is needed to build a strong community in the future. The purpose of education is to create a character and culture, both obtained formally and informally. Education takes time to change people's attitudes and behaviour. The education of environmental-care characters is important to be given to students from early childhood, elementary to university levels, because it can provide experience in five different areas: knowledge, awareness, behaviour, skills, and participation, therefore all those experiences can create human harmony with the environment.

Based on the results of the questionnaire, most of the second grade students of Economics Education of FKIP Unswagati expressed their concern to the environment in overcoming the scarcity of natural resources through environmental care attitude. They care about the environment by stating that they always maintain personal hygiene, rooms, homes, classrooms, 
campuses and neighborhoods with great sense of responsibility, without having to be reminded and ordered by others (parents, lecturers, or friends), that is by keeping the cleanliness of public facilities, always throwing the trash to the trash can, sparing using plastic bags that cannot be recycled, and remind each other in maintaining cleanliness and environmental sustainability. They are also always trying to use natural resources efficiently (electric energy and fuel oil), healthy living, as well as unpretentious. Similarly, the results of interviews, most of the second grade students of Economics Education of Unswagati Cirebon stated that the use of natural resources must be wise and economical so that the limited number of natural resources can be experienced by the next generation and there is no scarcity. Most of the students also stated that they want to actively participate in overcoming the scarcity of natural resources, and inviting their friends to participate in the effort to overcome the scarcity of natural resources in the future. This indicates that the purpose of the character education is achieved.

The objective of education of environment character towards the second grade students of Economic Education of FKIP Unswagati is not only to give knowledge, but also awareness, behavior, skills, and participation, as Muslich's opinion (2011: 210) that:

The education of environmental-care character is important to be given to students from early childhood, elementary to university levels, as they can provide experience in five different areas: knowledge, awareness, behaviour, skills, and participation, thus those experiences can create human harmony with the environment. Furthermore, the opinion is reinforced by Aqib's opinion (2012: 90) which suggests that:

Education character is closely related to the "habit" or habit that is continuously practiced. Extensively, education character is expected to touch the three domains (cognitive, affective, and psychomotor) of students, therefore students are not only knowing, but also willing and able to implement the truth they have known.

With giving the education of environmental character, although only a small part of the discussion of scarcity, students of Unswagati Cirebon can improve their environmental care attitude in overcoming the scarcity of natural resources which is now increasingly encouraged by all parties, both government and educational institutions (formal, informal, and non formal), for the sake of environmental sustainability and natural resources which are very important for human life.

\section{CONCLUSIONS}

Second grade Students of Economics Education of FKIP Unswagati has positive attitudes toward the care of environment and economical concern in using the natural resources. Although, the care attitude and thrifty is not always recognized and done continuously. Sometimes they care and save, while the others are ignorant. However, they are always aware on environmental care attitudes which means they have participated in undertaking the efforts of environmental conservation on behalf of overcoming the lack of the resources.

Environment education for the second grade students at Economic Education of FKIP Unswagati is not only improves knowledge, but also awareness, behaviour, skills, and participation in sustaining the environment. Specifically in maintaining, managing, preserving, and restoring the loss of environmental resources.

\section{ACKNOWLEDGMENT}

Our thanks goes to all those who have helped the implementation of this research, especially to four students at the second grade of the academic year 2016/2017; Wibowo, Rosadi, Nurjamilah Afifah, and Gina Amelia.

We also thank profusely to all parties for help, guidance, motivation and advice, therefore all difficulties and obstacles can we faced in arranging this paper. Hopefully this paper can provide many benefits, for researchers in particular, and the readers in general.

\section{REFERENCES}

Akhmad Fauzi, Ekonomi Sumber Daya Alam dan Lingkungan Teori dan Aplikasi, Jakarta: PT. Gramedia Pustaka Utama, 2006.

Amos Neolaka, Kesadaran Lingkungan, Jakarta: PT. Rineka Cipta, 2008. 
Anonimus, Kamus Besar Bahasa Indonesia, Jakarta: Balai Pustaka, . 2005.

Baharudin Supardi, Berbakti Untuk Bumi, Bandung: Rosdakarya, 2009.

Burhan Bungin, Penelitian Kualitatif: Komunikasi, Ekonomi, Kebijakan Publik, dan Ilmu Sosial Lainnya Edisi Kedua, Jakarta: Kencana Prenada Media Group, 2012.

Eeng Ahman dan Yana Rohmana, Teori Ekonomi Mikro, Bandung: Universitas Pendidikan Indonesia (UPI), 2009.

Endah Sulistyowati, Implementasi Kurikulum Pendidikan Karakter, Yogyakarta: Citra Aji Parama, 2012.

M.H. Huasein, Lingkungan Hidup: Masalah Pengelolaan dan Penegakan Hukumnya, Jakarta: PT. Bumi Aksara, 1993.

M. Muslich, Garis-Garis Besar Tata Bahasa Baku Bahasa Indonesia, Bandung: PT. Refika Aditama, 2011.

Nadjmuddin Ramly, Membangun Lingkungan Hidup yang Harmonis \& Berperadaban, Jakarta: Grafindo Khazanah Ilmu, 2005.
N. Gregory Mankiw, Euston Quah, dan Peter Wilson, Pengantar Ekonomi Mikro Edisi Asia, Jakarta: Salemba Empat, 2012.

Otto Soemarwoto, Ekologi Lingkungan Hidup dan Pembangunan, Bandung: Djambatan, 1994.

Prabang Setyono, Etika, Moral, dan Bunuh Diri Lingkungan dalam Perspektif Ekologi (Solusi Berbasis Enviromental Insight Quotient), Surakarta: UNS Press and LPP UNS, 2011.

Pusat Informasi Lingkungan [PIL]. (2009) Kebijakan Pendidikan Lingkungan Hidup. [Online]. Available: http://www.pil.or.id/.

Sadono Sukirno, Mikro Ekonomi Teori Pengantar Edisi Ketiga, Jakarta: Rajawali Pers, 2011.

Sugiyono, Metode Penelitian Kuantitatif, Kualitatif, Dan $R \&$ \& , Bandung: Alfabeta, 2014.

Zainal Aqib, Pendidikan Karakter Di Sekolah: Membangun Karakter dan Kepribadian Anak, Bandung: Yrama Widya, 2012. 